ISAHP 2005, Honolulu, Hawaii, July 8-10, 2003

\title{
Using ANP for Evaluating Value Position of Industrial Cluster Effect
}

\author{
Hsiao-Chi Chen, Joseph Z. Shyu \\ Institute of Management of Technology, National Chiao Tung University, \\ 1001, Ta-Hsueh Rd., Hsinchu 300, Taiwan \\ Tel: 886-5-5712121 ext.57518 Fax: 886-5-5726749 \\ angela77.mt90g@nctu.edu.tw; joseph@cc.nctu.edu.tw
}

Key words: ANP, value position, Science Park, cluster effect, innovation

Summary: This paper argues what the value position of cluster is. We address transaction cost and network effect to define the value of industrial cluster. There are six critical resources from cluster, including venture capital, talent pool, universities and research institutes, support infrastructure, lead users, and entrepreneurial spirit. Therefore, ANP method is used to investigate the major value position of cluster for solving the relation to criteria. The companies of Hsinchu Science Park in Taiwan are illustrated to affect of cluster. The analysis leads to the conclusion that the transaction cost and innovation network effect link innovation activities to make cluster recycle. Among that, entrepreneurial spirit, support infrastructure and talent pool are also the major value positions of the industrial cluster effect.

\section{Introduction}

Science high-technology firms in Silicon Valley prosper in a constantly changing environment of incessant novelty and innovation, regional technology clusters are had sprouted around global in recent years. Additionally, there are a number of government-sponsored science park initiatives, such as France's Sofia Antipolis, Taiwan’s Hsinchu, and U.K.’s Cambridge (Garnsey and Brookes, 1992). The success experience of Hsinchu Science Park in Taiwan is studied and simulated from other countries, especially in China. Science Park model are used to develop economic growth fast. Furthermore, Science Park has cluster effect, engaging talent and support institutes, accelerating knowledge circulation and so on. Geographical proximity stimulates networking between firms, thereby facilitating imitation and improvement.

Industry faces four steps to change, i.e. introduction stage, growth stage, maturity stage, and decline stage, which called industry life cycle (Anderson and Zeithaml, 1984). With industry development, 
innovation makes industry recycle. Innovation provides revive capability to industry. Science Park in particular, shows innovation how to cause industry recycle and revive. In industry innovation system, cluster effect has become the dominant innovation driver of the Science Park. The industrial cluster integrate many resources and elements, which make innovation occurring. But "what is major effects of industrial cluster?”. This paper argues what the value position of cluster is. Hence, ANP (analytic network process) is used to evaluate critical value position of cluster effect.

Even though clusters of knowledge-based high technology and other highly dynamic sectors have benefits, when face environment changing, the centralized characteristic of same businesses will lose flexibility. Rosenfeld (1997) using case studies to show there is relevance of clustering to localized economic development. However, academic literature still views the geographic relationship within clusters as a theory based on observation, but not yet proven (Anderson, 1994). Whether the cluster effect can be created by given the same elements? Which becomes the government policy is used in China. We purpose a model to describe cluster effect if possible is copied. It shows presence of cluster effect. We address transaction cost and network effect to define the value of cluster, then, investigating value position of cluster effect from these two indexes.

This paper is organized as follows. Section 2 reviews cluster and transaction cost of the literature. Section 3 discusses the determinant and a general model of cluster is built. Section 4 describes the samples of research case-HsinChu Science Park and shows the results. Finally, Section 5 presents some concluding remarks.

\section{Studies reviews of cluster and methodology}

\subsection{Industrial cluster}

An industrial cluster is a group of companies that rely on an active set of relationships among themselves for individual efficiency and competitiveness (Anderson, 1994). The essence of industrial clusters lies in the ability to develop relationships through strategic partnerships between companies, customers, suppliers, research \& education institutions, and the wider business community.

The idea of clusters is not new. Conceptually the literature is developed from regional agglomeration economies theory in $18^{\text {th }}$ century. Marshall (1920) paid much attention to it in his study of industries in the United Kingdom in the early $20^{\text {th }}$ century. Recently the concept of industrial clusters has become fairly standard in economic development literature in 1990s. Porter (1990) introduced SRI International first used "industrial cluster" in a consulting project for a southern California utility in 1988. He argues that competitive advantage and strong industrial clusters are inter-related and that successful clusters drive economic development. 
The advantages of industrial clustering for internationally competitive sectors such as the semiconductor industry have been extensively surveyed in the literature (Piore \& Sabel, 1984; Best, 1990; Porter, 1990). There seems to be an agreement and consensus that clusters provide general benefits to firms, especially in the value chain inputs as well as in the general aspects of the production process (Marshall, 1920; Weber, 1929; Porter, 1990; Krugman, 1991; Malmberg et al, 1996; Storper and Salais, 1997; Baptista, 1998; Porter, 1998; Asheim and Cooke, 1999; Schmitz, 1999; Freel, 2000).The clustered location patterns of these vertically-integrated semiconductor firms have much more in common with the 'industrial complex' model of location (McCann et al, 2002), and is typical of the information internalization behavior of MNEs in other locations (McCann, 1997) and other sectors (Simmie, 1998). Past literatures show that industrial cluster play a major role in industry development. Therefore, we study value position of industrial cluster to define how cluster benefit industry development.

\subsection{The analytic network process (ANP)}

The ANP was proposed in (Saaty, 1996; Saaty and Vargas, 1998) to overcome the problem of interdependence and feedback between criteria or alternatives. The ANP is the general form of the analytic hierarchy process (AHP) (Saaty, 1980) which has been used in multicriteria decision making (MCDM) to release the restriction of hierarchical structure, and has been applied to project selection (Meade and Presley, 2002; Lee and Kim, 2000), product planning, strategic decision (Sarkis, 2003; Karsak et al., 2002), optimal scheduling (Momoh and Zhu, 2003) and so on.

ANP analysis is to evaluate the weights of objects by the so called super matrix S. The influence of elements in the network on other elements in that network can be represented in the following super matrix. The following super matrix, which consists many block matrixes $\left(W_{i, j} ; i, j=1,2, \ldots, h\right)$ is used to identify the interactive priorities of the aforementioned system (Saaty, 1999):

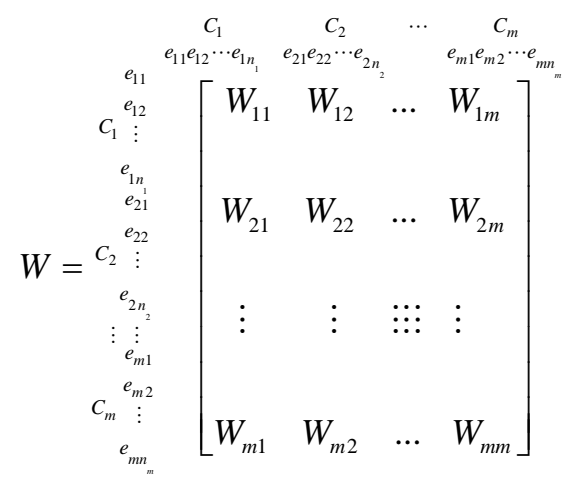

where denote a component of a decision network by $C_{h}, h=1, \ldots, m$, and assume that it has $n_{h}$ 
elements, which we denote by $e_{h 1}, e_{h 2}, \ldots, e_{h m_{h}} . W_{i j}$ is the principal eigenvector of the influence of the elements compared in the $j$ th cluster to the $i$ th cluster. In addition, if the $i$ th cluster has no influence to the ith cluster, then $W_{i j}=0$.

In order to calculate the weights of objects in ANP, Saaty (1996) uses the limiting process $\lim _{v \rightarrow \infty} S^{v}$, but it is clear that weight vector $u$ of objects in ANP is the solution of the equation $S_{u}=u$ if $S$ is a stochastic matrix, which is always required in ANP (Sekitani and Takahashi, 2001).

\section{The Determinant of Industrial Cluster}

In Bahrami and Evans studied for Silicon Valley (1995), there are several components—each playing different and mutually supportive roles—of Silicon Valley's versatile ecosystem. Constituents of Science Park's ecosystem include venture capitalists (Hambrecht, 1984), a global talent pool of knowledge professionals, universities and research institutes, a sophisticated service infrastructure, as well as many customers, leaders (Schumpeter, 1974), and early adopters of new technologies. Many studies ever used these constituents to analyze the development of Science Park. This article took these elements to define the cluster effort of Science Park model.

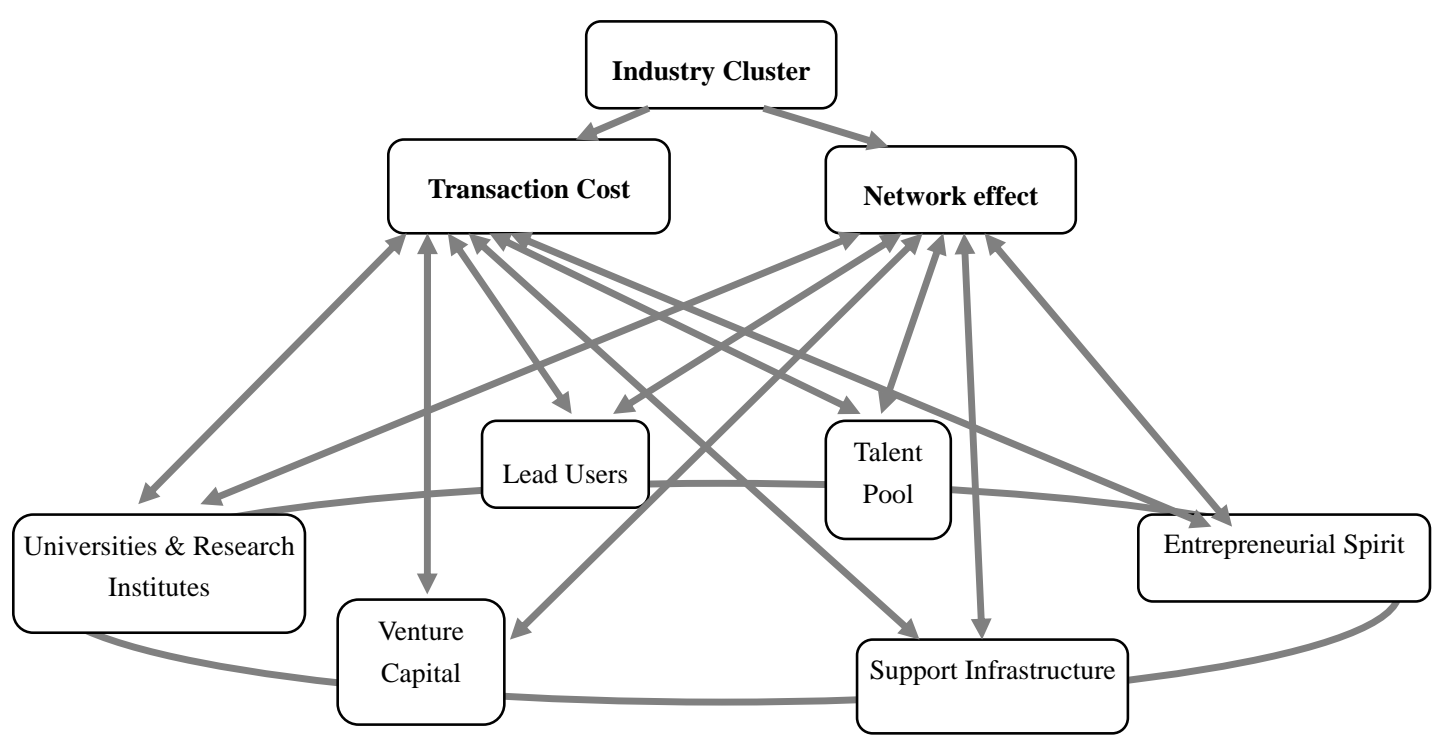

Fig. 1 The interaction structure of industrial cluster

In many cases, a lack of data on local and interregional industrial linkages, shared business institutions, 
channels of technology and knowledge transfer, and other dimensions of the cluster concept. This paper integrates transaction cost and network effect to explain complex motion in cluster and its value position. With previous researches, there are collated six critical resource of cluster (criteria): entrepreneurial spirit, support infrastructure, venture capital, universities \& research institutes, lead user, and talent pool. These six criteria represent resource of industrial cluster. There are dynamic interactions between the two measure dimension and six criteria, like Fig 1.

\section{Research Case: HsinChu Science Park}

In Hsinchu Science Park, some 393 established technology-based firms, including tsmc, UMC, D-link, etc., are supported by a growing network of specialty suppliers of related products, services, resources, and components. This paper focus on industrial cluster effect, therefore, Hsinchu Science Park is mainly made up information technology industry. In these technology-based firms, there are 28 Bio-technology companies. In questionnaire survey, bio-technology firms are not the object of this research. In addition to 28 bio-companies, we adopt random sampling sending requested questionnaire to 250 firms in Hsinchu Science Park. We collected the samples by interviews. Rate of questionnaire returned is $12 \%$ in this research. Interviewing target in this research all are the high-level managers in Hsinchu Science Park. Undoubtedly, we concluded whole parts of such a questionnaire are reliable and convincible. Table 1 shows the collected sample by industries, qualifications, and occupational seniorities.

Table 1 Industrial cluster effect questionnaire profile

\begin{tabular}{|c|c|c|c|c|c|}
\hline $\begin{array}{c}\text { Industrial cluster effect } \\
\text { questionnaire }\end{array}$ & Sample & $\begin{array}{c}\text { Percentage } \\
(\%)\end{array}$ & \begin{tabular}{|c} 
Industrial cluster effect \\
questionnaire
\end{tabular} & Sample & $\begin{array}{c}\text { Percentage } \\
(\%)\end{array}$ \\
\hline Industries & & & Occupational seniorities & & \\
\hline IC industry & 18 & 0.6 & Below 5 years & 0 & 0 \\
\hline PC and peripheral & 1 & 0.033 & $5-10$ years & 7 & 0.233 \\
\hline telecommunication & 6 & 0.2 & $10-15$ years & 9 & 0.3 \\
\hline Opt-electronics industry & 1 & 0.033 & $15-20$ years & 7 & 0.233 \\
\hline Precision machinery & 1 & 0.033 & Over 20 years & 7 & 0.233 \\
\hline Others & 3 & 0.1 & & & \\
\hline \multicolumn{6}{|l|}{ Qualifications } \\
\hline Secondary school & 2 & 0.067 & & & \\
\hline HND diploma/ certificates & 25 & 0.833 & & & \\
\hline Degree & 2 & 0.067 & & & \\
\hline Graduate institute or above & 1 & 0.033 & & & \\
\hline
\end{tabular}

The purpose of this empirical study is to investigate the major value position of cluster. Transaction 
cost and network effect are high relation to industrial cluster by generalizing from literature reviews and expert opinion. These are two aspects to evaluate industrial cluster effect. By these two objectives, we evaluate six resources in industrial cluster. First, we got an unweighted super matrix (Table 2). With measure relation between every cluster in goal (industrial cluster effect), we got a weighted super matrix (Table 3). In Table 3, Entrepreneurial spirit (0.131188), and talent pool (0.180448) are critical value position in transaction cost dimension. That expresses: easy getting human resource and manager's venturous leadership are decisive issues for firms when measure in transaction cost. Among transaction cost influence, network effect has low impact for industrial cluster, only 0.296416.

In network effect dimension, there are support infrastructure (0.196479) and talent pool (0.249075) locating key position of industrial cluster mechanism. Government support variety infrastructure, including preferential policy (tax, interest rate, etc.) and peripheral infrastructure (road, bank, etc.). These support infrastructures are essential to cluster network operation. Additionally, enough talent is another essential factor to assist cluster network working. But different in the foregoing, transaction cost is still considered among network effect influence. It has high impact (0.43745) for industrial cluster. That means firms would even consider cost problem when industry network working high performance.

Table 2 Unweighted super matrix

\begin{tabular}{|l|c|c|c|c|c|c|c|c|c|}
\hline \multirow{2}{*}{\begin{tabular}{c} 
Lluster Node \\
\cline { 2 - 10 }
\end{tabular}} & $\begin{array}{c}\text { Entrepreneur } \\
\text { ial spirit t }\end{array}$ & Lead users & $\begin{array}{c}\text { Support } \\
\text { infrastructure }\end{array}$ & Talent Pool & $\begin{array}{c}\text { Universities } \\
\text { \& Research } \\
\text { institutes }\end{array}$ & $\begin{array}{c}\text { Venture } \\
\text { capital }\end{array}$ & $\begin{array}{c}\text { Transaction } \\
\text { cost }\end{array}$ & $\begin{array}{c}\text { Network } \\
\text { effect }\end{array}$ & $\begin{array}{c}\text { Industrial } \\
\text { Cluster Effect }\end{array}$ \\
\hline $\begin{array}{l}\text { Entrepreneurial } \\
\text { spirit }\end{array}$ & 0 & 0 & 0 & 0 & 0 & 0 & 0.180459 & 0.164626 & 0 \\
\hline Lead users & 0 & 0 & 0 & 0 & 0 & 0 & 0.164085 & 0.163358 & 0 \\
\hline $\begin{array}{l}\text { Support } \\
\text { infrastructure }\end{array}$ & 0 & 0 & 0 & 0 & 0 & 0 & 0.161245 & 0.196479 & 0 \\
\hline Talent pool & 0 & 0 & 0 & 0 & 0 & 0 & 0.25829 & 0.243075 & 0 \\
\hline $\begin{array}{l}\text { Universities \& } \\
\text { Research } \\
\text { institutes }\end{array}$ & 0 & 0 & 0 & 0 & 0 & 0 & 0.089324 & 0.132378 & 0 \\
\hline Venture capital & 0 & 0 & 0 & 0 & 0 & 0 & 0.146599 & 0.100088 & 0 \\
\hline Industrial Cluster & 0 & 0 & 0 & 0 & 0 & 0 & 0 & 0 & 0 \\
\hline Transaction cost & 1 & 1 & 1 & 1 & 1 & 1 & 0 & 1 & 1 \\
\hline Network effect & 1 & 1 & 1 & 1 & 1 & 1 & 1 & 0 & 1 \\
\hline
\end{tabular}

Table 3 Weighted super matrix

\begin{tabular}{|c|c|c|c|c|c|c|c|c|c|}
\hline $\begin{array}{c}\text { Cluster Node } \\
\text { Labels }\end{array}$ & \multicolumn{4}{|c|}{ Criteria } & \multicolumn{3}{|c|}{ Objective } & Goal \\
\cline { 2 - 8 } & $\begin{array}{c}\text { Entrepreneur } \\
\text { ial spirit t }\end{array}$ & Lead users & $\begin{array}{c}\text { Support } \\
\text { infrastructure }\end{array}$ & Talent Pool & $\begin{array}{l}\text { Universities } \\
\text { \& Research } \\
\text { institutes }\end{array}$ & $\begin{array}{c}\text { Venture } \\
\text { capital }\end{array}$ & $\begin{array}{c}\text { Transaction } \\
\text { cost }\end{array}$ & $\begin{array}{c}\text { Network } \\
\text { effect }\end{array}$ & $\begin{array}{c}\text { Industrial } \\
\text { Cluster Effect }\end{array}$ \\
\hline
\end{tabular}




\begin{tabular}{|l|c|c|c|c|c|c|c|c|c|}
\hline $\begin{array}{l}\text { Entrepreneurial } \\
\text { spirit }\end{array}$ & 0 & 0 & 0 & 0 & 0 & 0 & 0.131188 & 0.099926 & 0 \\
\hline Lead users & 0 & 0 & 0 & 0 & 0 & 0 & 0.111656 & 0.079107 & 0 \\
\hline $\begin{array}{l}\text { Support } \\
\text { infrastructure }\end{array}$ & 0 & 0 & 0 & 0 & 0 & 0 & 0.116759 & 0.108244 & 0 \\
\hline Talent pool & 0 & 0 & 0 & 0 & 0 & 0 & 0.180448 & 0.137872 & 0 \\
\hline $\begin{array}{l}\text { Universities \& } \\
\text { Research } \\
\text { institutes }\end{array}$ & 0 & 0 & 0 & 0 & 0 & 0 & 0.064359 & 0.076425 & 0 \\
\hline Venture capital & 0 & 0 & 0 & 0 & 0 & 0 & 0.099176 & 0.060977 & 0 \\
\hline Industrial Cluster & 0 & 0 & 0 & 0 & 0 & 0 & 0 & 0 & 0 \\
\hline Transaction cost & 0.371922 & 0.371922 & 0.371922 & 0.371922 & 0.371922 & 0.371922 & 0 & 0.43745 & 0.371922 \\
\hline Network effect & 0.628078 & 0.628078 & 0.628078 & 0.628078 & 0.628078 & 0.628078 & 0.296416 & 0 & 0.628078 \\
\hline
\end{tabular}

After getting weighted super matrix, limiting super matrix is produced by limiting result of weighted matrix. In Table 4, priorities of goal (industrial cluster effect) are found by limiting. With limiting ever node of cluster effect network structure, talent pool (0.097235), transaction cost (0.280258), and network effect (0.332804) are key elements to create industrial cluster effect. Furthermore, they are firms' critical value obtaining from industrial cluster. In industrial cluster (like Hsinchu Science Park), it would attract talents assembling into talent pool, which support every high-tech industry development. Low transaction cost and high network effect are other two advantages produce following industrial cluster.

Industrial cluster are affected by all determinants co-operation, with transaction cost and network effect catalytic. If normalized by cluster, Entrepreneurial spirit (0.177676), support infrastructure (0.175101), and talent pool (0.24729) are shown their importance in all determinants. For firms in Science Park, Entrepreneurial spirit and support infrastructure is indispensable resource from cluster effect besides talent pool. Additionally, network effect (0.548332) plays a more critical role than transaction cost (0.451668) in industrial cluster. That shows network effect is major dimension to stimulate firms moving into Science Park. By industrial cluster get network effect in industry supply-chain.

Table 4 Priorities of industrial cluster effect

\begin{tabular}{|c|c|c|}
\hline \multirow{3}{*}{ Cluster Node Labels } & Goal & \multirow[b]{3}{*}{ Normalized By Cluster } \\
\hline & Industrial Cluster Effect & \\
\hline & limiting & \\
\hline Entrepreneurial spirit & 0.068692 & 0.177676 \\
\hline Lead users & 0.059341 & 0.159547 \\
\hline Support infrastructure & 0.068042 & 0.175101 \\
\hline Talent pool & 0.097235 & 0.24729 \\
\hline $\begin{array}{l}\text { Universities \& Research } \\
\text { institutes }\end{array}$ & 0.044094 & 0.11357 \\
\hline
\end{tabular}




\begin{tabular}{|l|c|c|}
\hline Venture capital & 0.049536 & 0.126815 \\
\hline Industrial Cluster & 0 & 0 \\
\hline Transaction cost & 0.280258 & 0.451668 \\
\hline Network effect & 0.332804 & 0.548332 \\
\hline
\end{tabular}

\section{Conclusion}

Innovation makes cluster development recycle. Cluster effect in particular has become the dominant innovation driver of the Science Park. The transaction cost and innovation network effect link innovation activities to make cluster recycle. In our empirical study of Hsinchu Science Park, we find entrepreneurial spirit, support infrastructure and talent pool are major resource to influence industrial cluster effect. Innovation is created from possessing entrepreneurial spirit and good talents, which has variety infrastructure supporting. Additionally, network effect and transaction cost play an important role in industrial cluster mechanism. For these two aspects, there are different results in value position of industrial cluster. Entrepreneurial spirit and talent pool are critical value position in transaction cost dimension. In another dimension of network effect, support infrastructure and talent pool are key position of industrial cluster mechanism.

At these empirical results, industrial cluster effect through an interconnected network of resources possessing. By analysis value position of industrial cluster, the results would support science and technology policy planning of government. In addition to policy drawing up, that also let firms to recognize their circumstance in cluster, and making suitable strategy. In this paper, we set up a simple model to define industrial cluster effect. Moreover, we create evaluative point to estimate "what is industrial cluster effect?". With value position, that provides an aspect to describe cluster effect if possible for being copied. Comparisons and analysis cluster effect of each Science Park (in particular China) in these value positions deserve to be investigated in future research.

\section{Reference}

Anderson, C. R., Zeithaml, C. P. (1984), "Stage of the product life cycle, business strategy, andbusiness performance”, Academy of Management Journal, 27, 5-24.

Anderson, G. (1994), “Industry clustering for economic development”, Economic Development Review, 12 (2), 26-32.

Asheim, B., Cooke, P. (1999), "Local learning and interactive innovation networks in a global economy”, in Malecki and Oinas (eds), Making Connection: Technological Learning and regional Economic Change, Ashgate, Aldershot, 145-178. 
Bahrami, H., Evans, S. (1995), "Flexible re-cycling and high-technology entrepreneurship”, California Management Review, 37 (3), 62-89.

Baptista, R. (1998), “Clusters, Innovation and Growth: A survey of the literature”, in Swann, P.; Prevexer, M.; Stout, D. (eds), The Dynamics of Industrial Clustering - International Comparisons in Computing and Biotechnology, New York: Oxford University Press.

Best, M. H. (1990), The new competition: Institutions of industrial restructuring, Cambridge: Polity Press.

Freel, M. (2000), "External linkages and product innovation in small manufacturing firms", Entrepreneurship and Regional Development, 12, 245-266.

Garnsey, E., Brookes, A.C. (1992), “The Cambridge phenomenon re-visited”, Research Paper, Judge Institute of Management Studies, Cambridge University.

Hambrecht, W.R. (1984), "Venture capital and the growth of Silicon Valley”, California Management Review, 26 (2).

Krugman, P. (1991), "Increasing returns and economic geography”, Journal of Political Economy, 99, 483-499.

Karsak, E.E., Sozer, S., Alptekin, S.E. (2002), "Product planning in quality function deployment using a combined analytic network process and goal programming approach”, Computers \& Industrial Engineering, 44 (1), 171-190.

Lee, J.W., Kim, S.H. (2000), "Using analytic network process and goal programming for interdependent information system project selection”,. Computers \& Operations Research, 27 (4), 367-382.

Malmberg, A., Sölvell, Ö., Zander, I. (1996), “Sparital clustering, local accumulation of knowledge and firm competitiveness”, Geografiska Annaler, 78 (2), 85-97

Marshall, A. (1920), Principles of Economics: An introductory volume, London: Macmillan.

McCann, P. (1997), “How deeply embedded is ‘Silicon Glen’? A cautionary note”, Regional Studies, 31(7), 695-703.

McCann, P., Arita, T., Gordon, I.R. (2002), "Industrial clusters, transactions costs and the institutional determinants of MNE location behavior”, International Business Review, 11, 647-663.

Meade, L.M., Presley, A. (2002), "R\&D project selection using the analytic network process”, IEEE Transactions on Engineering Management, 49(1), 59-66. 
Momoh, J.A., Zhu, J. (2003), “Optimal generation scheduling based on AHP/ANP”, IEEE Transaction on Systems Man and Cybernetics Part B- Cybernetics, 33 (3), 531-535.

Piore, M.J., Sabel, C.F. (1984), The second industrial divide: possibilities for prosperity, New York: Basic Books.

Porter, M. (1990), The competitive advantage of nations, New York: Free Press.

Porter, M. (1998), “Clusters and the new economics of competitiveness”, Harvard Business Review, December, 77-90.

Rosenfeld, S.A. (1997), "Bringing business clusters into the mainstream of economic development”, European Planning Studies, 5 (1), 3-23.

Saaty, T.L. (1980), The Analytic Hierarchy Process, New York: McGraw- Hill.

Saaty, T.L. (1996), Decision Making with Dependence and Feedback: The analytic network process, Pittsburgh: RWS Publications.

Saaty, T.L., Vargas, L.G. (1998), “Diagnosis with dependent symptoms: Bayes theorem and the analytic hierarchy process”, Operations Research, 46 (4), 491-502.

Saaty, T.L. (1999), "Fundamentals of the analytical network process”, Proceeding of ISAHP 1999, Aug. 12-14, Kobe, Japan.

Sarkis, J. (2003), “A strategic decision framework for Green supply chain management”, J. Cleaner Production, 11 (4), 397-409.

Schmitz, H. (1999), "From ascribed to earned trust in exporting clusters", Journal of International Economics, 48, 139-150.

Schumpter, J.A. (1974), “The creative response in economic history”, Journal of Economic History, 7, November, 149-159.

Sekitani, K., Takahashi, I. (2001), “A unified model and analysis for AHP and ANP”, Journal of the Operations Research Society of Japan, 44 (1), 67-89.

Simmie, J. (1998), “Reasons for the development of ‘islands of innovation’: evidence from Hertfordshire”, Urban Studies, 35 (8), 1261-1289.

Storper, M., Salais, R. (1997), Wold of production, London: Hardvard University Press.

Weber, A. (1929), Theory of the Location of Industries, The University of Chicago Press, Chicago \& London (English translation by Carl J. Friedrich of “Ueber den Standort der Industrien”). 